\title{
Pontiac fever: an operational definition for epidemiological studies
} Paul Tossa1, Magali Deloge-Abarkan¹, Denis Zmirou-Navier ${ }^{1}$, Philippe Hartemann ${ }^{1}$ and Laurence Mathieu*2

\author{
Address: ${ }^{1}$ Département Environnement et Santé Publique and INSERM ERI 11, Henri Poincaré University; Nancy, School of Medicine - 9 avenue

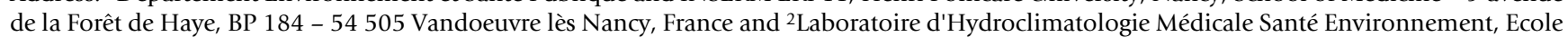 \\ Pratique des Hautes Etudes (EPHE) and INSERM ERI 11; Nancy, School of Medicine - 9 avenue de la Forêt de Haye, BP 184 - 54505 Vandoeuvre- \\ lès-Nancy, France \\ Email: Paul Tossa - Paul.Tossa@nancy.inserm.fr; Magali Deloge-Abarkan - Magali.deloge@medecine.uhp-nancy.fr; Denis Zmirou- \\ Navier - Denis.Zmirou@nancy.inserm.fr; Philippe Hartemann - philippe.hartemann@medecine.uhp-nancy.fr; \\ Laurence Mathieu* - laurence.mathieu@medecine.uhp-nancy.fr \\ * Corresponding author
}

Published: 28 April 2006

BMC Public Health2006, 6:1 I2 doi:10.1 I86/I47|-2458-6-II2

This article is available from: http://www.biomedcentral.com//47/-2458/6/II2

(c) 2006Tossa et al; licensee BioMed Central Ltd.

This is an Open Access article distributed under the terms of the Creative Commons Attribution License (http://creativecommons.org/licenses/by/2.0), which permits unrestricted use, distribution, and reproduction in any medium, provided the original work is properly cited.
Received: 08 November 2005

Accepted: 28 April 2006

\begin{abstract}
Background: Pontiac fever is usually described in epidemic settings. Detection of Pontiac fever is a marker of an environmental contamination by Legionella and should thereby call for prevention measures in order to prevent outbreak of Legionnaire's disease. The objective of this study is to propose an operational definition of Pontiac fever that is amenable to epidemiological surveillance and investigation in a non epidemic setting.
\end{abstract}

Methods: A population of 560 elderly subjects residing in 25 nursing homes was followed during 4 months in order to assess the daily incidence of symptoms associated, in the literature, with Pontiac fever. The water and aerosol of one to 8 showers by nursing home were characterized combining conventional bacterial culture of Legionella and the Fluorescence In Situ Hybridization (FISH) technique that used oligonucleotides probes specific for Legionellaceae. A definition of Pontiac fever was devised based on clinical symptoms described in epidemic investigations and on their timing after the exposure event. The association between incidence of Pontiac fever and shower contamination levels was evaluated to test the relevance of this definition.

Results: The proposed definition of Pontiac fever associated the following criteria: occurrence of at least one symptom among headache, myalgia, fever and shivers, possibly associated with other 'minor' symptoms, within three days after a shower contaminated by Legionella, during a maximum of 8 days (minimum 2 days). 23 such cases occurred during the study (incidence rate: 0.125 cases per person-year [95\% Cl: 0.122-0.127]). A concentration of Legionella in water equal to or greater than $10^{4} . \mathrm{L}^{-1}$ (FISH method) was associated with a significant increase of incidence of Pontiac fever $(p=0.04)$.

Conclusion: Once validated in other settings, the proposed definition of Pontiac fever might be used to develop epidemiological surveillance and help draw attention on sources of Legionella. 


\section{Background}

Pontiac fever (PF) is the mild form that takes infection by Legionella. It usually appears on an epidemic mode and is not associated with pneumonia [1]. Like for Legionaires' disease, infection stems from inhalation of an aerosol contaminated by Legionella [2]. Clinically, Pontiac fever's symptoms mimic influenza, with fever, asthenia, myalgia, arthralgia, headache, cough, nausea and sore throat $[1,3]$; other symptoms such as dyspnea, thoracic pains [2-4] vomiting and diarrhoea $[3,5,6]$ have also been described. Patients recover in two to five days, without treatment [79].

Because of its benignity and lack of specificity, the occurrence of PF is often undiagnosed and is therefore less reported than Legionnaires' disease. Epidemiologically, PF is characterized by a short incubation period (typically 30 to 90 hours, with an average of $36 \mathrm{~h}$ ), a high attack rate (70 to $90 \%$ ) [1], and absence of fatalities or long term complications [2]. Age, gender and smoking do not seem to be risk factors $[10,11]$. Rather, PF seems to affect preferentially young subjects: the age of cases was 36 to 39 years in the original Pontiac episode $[12,13]$, and age medians during different documented epidemics were $29[4,10]$, 30 [3] and 32 years [11]. Pathogenesis of the PF is poorly known. To date, there is no consensus on the duration of the incubation period, on its clinical symptoms, nor on the causal species of Legionella.

Different serogroups (SGs) of Legionella pneumophila ( $L p$ ) (1, 6 and 7) [14-16], as well as L. feeleii [12,17], L. micdadei $[2,11,12]$, L. anisa [13] can cause PF. In terms of diagnosis, according to some authors, PF develops the same serological characteristics as Legionnaires'disease $[10,18]$. Others claim on the contrary that serology during of a PF is inconstantly positive [19]. Presence of urinary antigen is not systematic either, even for epidemics connected to $L p$ SG $1[10,20]$.

Detection of PF is a marker of an environmental contamination by Legionella and should thereby call for prevention measures. Efforts to standardize the definition of PF may facilitate comparison of risk levels and help draw attention on sources of Legionella. In this article, based on data from the Legion'Air project, we propose an operational definition of PF for the purpose of surveillance and epidemiological studies.

\section{Methods}

The objectives of the Legion'Air project are: 1) to assess the exposure of elderly people residing in nursing homes to Legionella through aerosols generated by hot-water during showers, and 2) to evaluate the risk that is associated with this exposure.
Nursing homes solicited to participate in the Legion'Air project were located in the Lorraine region, north east of France. The selection process was based on the capacity of the nursing homes and on practical considerations (it should be located not too far from the study centre); no consideration was given to prior knowledge of contamination of the hot water system, in order to prevent selection bias.

This epidemiological study is a retrospective follow-up study. A population of 560 elderly volunteers (informed consent was obtained from patients or guardians) have been followed during 4 months. A set of predefined symptoms were registered daily by the auxiliary nursing staff, symptoms that had been previously reported in the literature in case of PF (table 1). Data were collected on demographic characteristics, current and/or past smoking habits, relevant medical history (respiratory and immunity-related conditions, such as diabetes and cancer) and current prescription of immunosuppressive therapy and of antibiotic medicines. A dedicated nurse insured the quality of recordings in the registers by alternating on site visits and telephone calls during the 4 months.

Volunteers included in the study were those who took at least one shower weekly. As shower practice represented the key exposure determinant (none of the participating nursing homes had air conditioning), data about shower habits were also recorded (the day and the room where the shower was taken).

At the end of the 4 months study, blood and urine samples were taken to assay anti Legionella antibodies and urine antigens of $L p$ SG 1 . The antibodies of interest were anti-Lp (SG 1 to 10) and other Legionella species (antiL.micdadei, anti-L.bozemanii, anti-L.dumoffii, anti-L.gormanii, anti-L.jordanis, anti-L.longbeachae SGs 1 and 2, antiL.anisa). All biological analyses were undertaken by the National Reference Center for Legionella in Lyon, France. Biological samples were collected and transported to guarantee their stability. The Nancy University Hospital ethics committee approved the study design and the biological sampling procedures.

To characterize exposure, shower water and aerosol of shower have been sampled. Sampling points were chosen in order to be representative of the exposure of the elderly volunteers. All showers could not be sampled, for practical and financial reasons. Thus, a prior evaluation of the hot water system (design, mode of hot-water production, maintenance of point-of-use, water temperature and treatment) was undertaken in each nursing home in order to assess its criticity in terms of Legionella risk and to identify the sampling points (showers) that fitted the best with the volunteers' exposure. Accordingly, each nursing home 
Table I: Clinical data during Pontiac fever episodes described in the literature [references]

\begin{tabular}{|c|c|c|c|c|c|c|}
\hline Reference & $\begin{array}{l}\text { Source of } \\
\text { exposure }\end{array}$ & $\begin{array}{l}\text { Incubation period } \\
\text { (hours) }\end{array}$ & $\begin{array}{l}\text { Episode } \\
\text { (duration) }\end{array}$ & Symptoms & Type and antibody titers & Legionella species \\
\hline [2] & $\begin{array}{l}\text { Spa with } \\
\text { jacuzzi/pool }\end{array}$ & $\begin{array}{l}\text { From } 9 \text { to } 67 \\
(\text { mean }=38)\end{array}$ & & $\begin{array}{l}\text { Myalgia }^{a}, \text { Headache }^{\text {ba }} \text {, Asthenia, } \\
\text { Shivers, Fever, Cough, Nausea, } \\
\text { Sore throatc Dyspneac }\end{array}$ & & L. micdadei \\
\hline [3] & $\begin{array}{l}\text { Washing } \\
\text { with high } \\
\text { pressure } \\
\text { water }\end{array}$ & & & $\begin{array}{l}\text { Fever }^{\mathrm{a}}, \text { Shivers }^{\mathrm{a}} \text {, Asthenia } \\
\text { Thoracic pain, Headache }^{\mathrm{b}} \text {, } \\
\text { Myalgia }^{\mathrm{b}} \text {, Nausea, Cough, } \\
\text { Dyspnea, Vomiting, Diarrhoea, } \\
\text { Abdominal pain, Ocular redness } \\
\text { with photophobia Sore throat }\end{array}$ & $\mathrm{I} / \mathrm{I} 28$ and $\mathrm{I} / 256$ & $\begin{array}{l}\text { L. pneumophila SGs } \\
\mathrm{I}, 3,4 \text { and } 6 \text { and L. } \\
\text { londiniensis }\end{array}$ \\
\hline$[4]$ & $\begin{array}{l}\text { Cooling } \\
\text { towers }\end{array}$ & 36 to 90 & 2 - 5 days & $\begin{array}{l}\text { Fever, Lombago, Arthralgia, } \\
\text { Headache, Dyspnea, Asthenia } \\
\text { Sore throat }\end{array}$ & Anti-Lp SG7I/I6 to $I / 256$ & L. pneumophila SG7 \\
\hline$[5]$ & $\begin{array}{l}\text { Decorative } \\
\text { fountains }\end{array}$ & 49 & 7I hours & $\begin{array}{l}\text { Fever }^{a} \text { Myalgia }^{b}, \text { Headache }^{b}, \\
\text { Shivers }^{b} \text {, asthenia, Back pain } \\
\text { Nausea, Cough, Vertigo Cramps } \\
\text { Diarrhoeac Vomiting }\end{array}$ & Anti-Anisa: $1 / 128$ to $1 / 512$ & L. Anisa \\
\hline [6] & $\begin{array}{l}\text { Spa with } \\
\text { jacuzzi/pool }\end{array}$ & & I - 5 days & $\begin{array}{l}\text { Diarrhoea, Vomiting, Headache, } \\
\text { Nausea, Myalgia, Coughc }\end{array}$ & Anti-Lp SG Titer >1/64 & L. pneumophila SG6 \\
\hline$[10]$ & $\begin{array}{l}\text { Cooling } \\
\text { towers }\end{array}$ & & & $\begin{array}{l}\text { Myalgia, Shivers, Asthenia, } \\
\text { Fever, Head ache }\end{array}$ & Urinary $\mathrm{Ag}$ & L. pneumophila SG I \\
\hline [26] & Spa & & & $\begin{array}{l}\text { Fever, Shivers, Thoracic pain, } \\
\text { Cough, Nausea }\end{array}$ & Anti-Lp SG6 & L. pneumophila SG6 \\
\hline
\end{tabular}

a : symptom met in all subjects ; b : symptoms met the most ; $\mathrm{c}$ : symptoms met the least;

was split, if appropriate, in several sectors. Study participants were allocated to each sector according to where they usually took their shower. One to eight showers were sampled by nursing home.

At the end of the follow-up, sampling of each shower point was performed twice, two days apart; only the hot water faucet was opened to its maximum flow. For each run, two water samples, collected in sterile bottles, were systematically taken: one on the first stream $(300 \mathrm{~mL})$; the other ( 1 litre) after 7 minutes of water draining (which is the average duration of a shower [21]).

Airborne and water Legionella was quantified by whole cell fluorescent in situ hybridisation (FISH) using a mix of three specific probes validated for Legionella [LEG705, LEG226 and LEGPNE1] [22,23]. In parallel with the FISH detection, the culturable fraction of Legionella was evaluated with the standard method (AFNOR NF T 90-431) [24]. The theoretical detection limits of the FISH technique in the study conditions are respectively $3.10^{2} / \mathrm{L}$ of air and $9.10^{3} / \mathrm{L}$ of water. Its specificity and sensitivity are $72 \%$ and $67 \%[25]$.

The bioaerosol sampling began only after the faucet of hot water was closed (i.e. after 7 minutes flushing). Two different biosamplers were used: a MAS- $100^{\circledR}$ (impaction on culture medium: GVPC) and an SKC Impinger (impaction on liquid medium: distilled water). Legionella count was done by culture using the MAS- $100^{\circledast}$ sampler (two air vol- umes were collected: $50 \mathrm{~L}$ and $500 \mathrm{~L}$ ), and by culture and the FISH technique using the Impinger (air volume collected: $195 \mathrm{~L})$.

\section{Case definition}

Table 1 summarizes descriptive data from the literature on $\mathrm{PF}$. The symptoms are not specific; there is not to date an agreed clinical definition of PF. Symptoms that predominate in the PF studies are headache, myalgia and fever and, to a lesser extent, shivers, a consequence of infection. These 4 symptoms will be qualified as "major symptoms". Similarly, the other symptoms showed in table 1 will be considered as "minor symptoms".

Based on these literature data, we chosen the interval of 24 to 72 hours after shower as the duration of the incubation period. Hereafter will be qualified as "evocative symptoms of a PF" these major symptoms, possibly associated to minor symptoms, insofar as they have occurred 24 to 72 hours subsequently to a shower. The duration of the PF episode reported in the literature varies from 1 to 5 days; we decided to spread this duration until a new exposure event (eg a new shower) without exceeding a maximal duration of 8 days. A case of PF will be then defined if all the following criteria are met: (i) it occurred within the three days after a shower and exhibited at least one of the major symptoms, associated or not with minor symptoms ; (ii) this episode lasted at least two days, not exceeding eight days ;(iii) since antibiotics treatment could mask some PF symptoms, we included in this definition all 
Table 2: Description of the population : age, gender, medical history and smoking status

\begin{tabular}{|c|c|c|c|c|c|c|c|}
\hline & Sample size & $\begin{array}{c}\text { Mean age } \\
\text { (standard-error) }\end{array}$ & $\begin{array}{l}\text { Previous } \\
\text { pathologies }\end{array}$ & $\begin{array}{l}\text { Previous immunity } \\
\text { conditions }\end{array}$ & $\begin{array}{l}\text { Previous respiratory } \\
\text { conditions }\end{array}$ & $\begin{array}{l}\text { Current } \\
\text { smokers }\end{array}$ & $\begin{array}{c}\text { Past } \\
\text { smokers }\end{array}$ \\
\hline Male & I58 (28.2\%) & $77( \pm 9)$ & II 17 (74.0\%) & 37 (23.4\%) & 20 (I2.6\%) & $20(12.7 \%)$ & 27 (17.1\%) \\
\hline Female & 402 (71.9\%) & $82( \pm 9)$ & $290(72.1 \%)$ & $94(24,3 \%)$ & 54 (I3.4\%) & 22 (5.5\%) & $4 \mid(10.2 \%)$ \\
\hline Total & $560(100 \%)$ & $81( \pm 9)$ & 407 (72.7\%) & $|3|(23.4 \%)$ & 74 (I3.2\%) & 42 (7.5\%) & $68(12.1 \%)$ \\
\hline
\end{tabular}

symptoms or association of symptoms lasting at least one day among subjects who had taken antibiotics this very day if at least one of these symptoms was a "major" one ; (iv) Legionella had to be detected in water and/or aerosol of the index shower that was selected as representing exposure of the case.

We explored two other definitions of a Pontiac episode, in a view to perform a sensitivity analysis. These alternative definitions focus on fever, viewed as the sole major symptom. In the first one, fever could be associated or not with another symptom (among those listed in table 1); in the second, fever was necessarily associated with at least one other symptom. All other criteria (lag after shower, duration of episode and contamination of water and/or of aerosol) were as described above.

\section{Data analysis}

Epi info version 3.3 and SAS were used for data management and analysis. All subjects were ascribed to a shower ward; those having used more than one shower in the course of the study were ascribed to the shower the most contaminated. The exposure value that was retained among the 6 samples available [ 4 water samples (two runs with two samples: first flow and after draining) and 2 aerosols samples (MAS-100 and SKC Impiger)] was the greatest Legionella count that was found, respectively by culture and by FISH.

For antibody titers, different "positivity" thresholds were tested. Legionella infection were considered as present beyond increasing sera titers, irrespective of the species or Legionella serogroups.

The association between the incidence of PF and contamination of showers were tested with chi squares on incidence rates, and the association with the prevalence of antibody titers by means of the regular chi square test. Tests are one sided, and $\mathrm{p}$ values are computed after the exact Fisher test.

\section{Results}

The study population consists in 560 elderly volunteers from 25 nursing homes of Lorraine. Their age and known risk factors are described in table 2 . Women represent more than $2 / 3$ of the study population and are, on aver- age, older than male volunteers $\left(\mathrm{p}<10^{-4}\right)$. Ages ranged from 46 to 102 years, the median value being 81 years. The population is constituted of $12.1 \%$ of ex-smokers and $7.5 \%$ of current smokers. Three quarters of subjects had a history of at least one previous medical condition (respiratory disorder, conditions impairing immunity or other), without gender difference.

\section{Incidence of Pontiac fever}

Among the 560 volunteers, 23 subjects had the clinical events corresponding to our definition of PF during the 4 months of follow-up; one subject had twice the clinical event, yielding 24 infectious episodes of PF. The global incidence rate was 0.125 cases per person-year [95\% confidence interval: 0.122-0.127]. These cases reside in 13 of the 25 nursing homes. For 10 homes, only one case was reported; two cases occurred in the same nursing home, 4 and 7 cases respectively in two other institutions. In addition to this space clustering, these cases exhibited a time aggregation: less than 10 days separated, respectively, the 2 and the 4 cases that occurred in the same nursing homes. The same held true for 5 out of the 7 cases that occurred in the same nursing home. Figure 1 displays the epidemic curves for these three nursing homes.

The different symptoms presented by cases are displayed in table 3 . The incubation period ranged from 24 to 72 hours, with an average and median of 48 hours. Average duration of a PF episode was 4 days. Sixteen subjects (respectively 14) met the two other definitions of a PF episode, yielding incidence rates of $0.08(0.07)$ cases per person-year.

\section{Biological results}

Antigenuria was negative for all subjects. The distribution of antibody titers, all Legionella species and SGs combined, is given in table 4. Up to antibody titers of $1 / 128$, the distribution of PF cases and of non cases were similar. But subjects with titers of $1 / 256$ had a greater probability to be a case compared to weaker titers $(\mathrm{RR}=3.45 ; \mathrm{p}=$ 0.12 ); the corresponding antibodies were anti- $L p$ SG 6 and anti-L.gormanii. On the other hand, it is noteworthy that 6 subjects who did not meet the definition criteria of PF had titers greater than $1 / 512$ for antibodies anti- $L p$ SG6, anti-L.jordanis, anti-L.micdadei, anti-L.dumoffii and anti-L.bozemanii. 


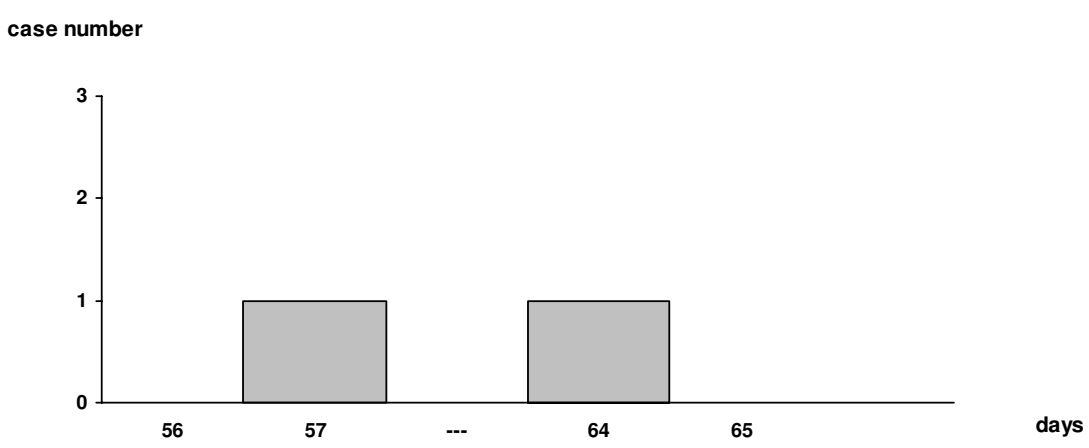

B

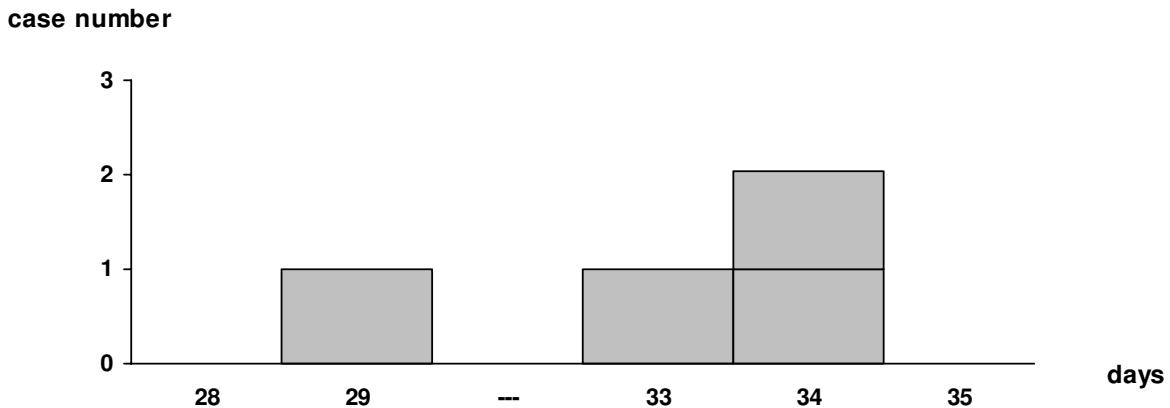

C

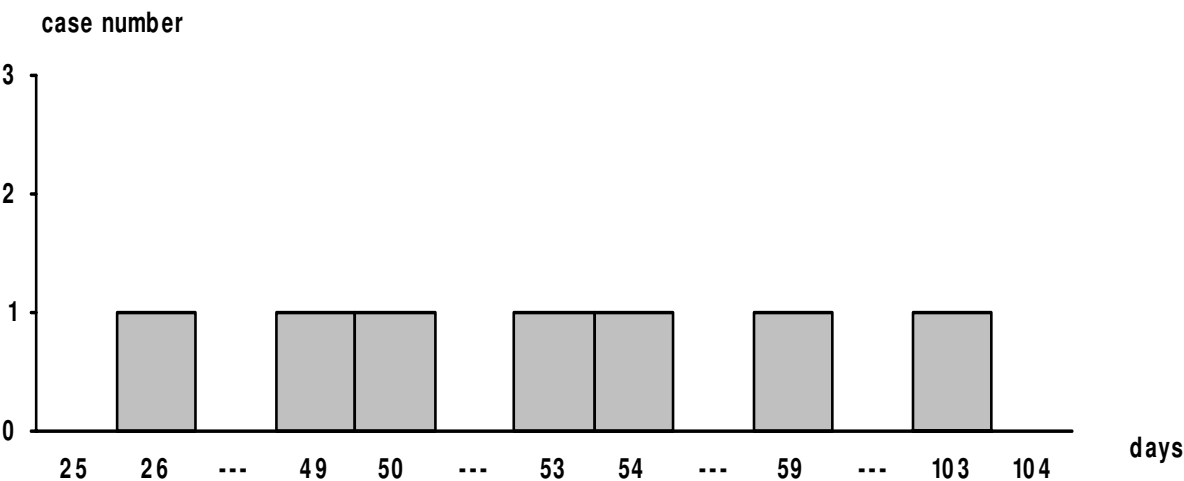

Figure I

Time distribution of PF cases in the nursing homes were more than one case occurred. A, B and C represent the nursing homes were more than one case occurred. "days" represents the days (since the beginning of follow up) at which Pontiac fever symptoms occurred. 
Table 3: Frequency of the different symptoms exhibited by the subjects who met Pontiac fever definition.

\begin{tabular}{lc}
\hline $\begin{array}{l}\text { Symptoms } \\
\text { (in bold « major » symptoms) }\end{array}$ & $\begin{array}{c}\text { Proportion of subjects } \\
\text { (\% among 24 episodes) }\end{array}$ \\
\hline Vertigo & $100 \%$ \\
Fever & $73 \%$ \\
Cough & $54 \%$ \\
Diarrhoea & $31 \%$ \\
Headache & $19 \%$ \\
Asthenia & $19 \%$ \\
Myalgia & $15 \%$ \\
Vomiting & $7 \%$ \\
Shivers & $4 \%$ \\
Nausea & $7 \%$ \\
Sore throat & $7 \%$ \\
Rhinorrhea & $4 \%$ \\
Abdominal pain & $4 \%$ \\
\hline
\end{tabular}

\section{Detection of Legionella in shower water}

Among the 23 subjects who presented at least one event defined as PF, Legionella have been detected in hot water of all the corresponding showers; they have also been found in the aerosol of 7 showers. Aerosolised Legionella was always associated with presence of bacteria in the water. Hence, only water contamination will be considered hereafter.

$L p$ was more frequent (66\% of positive samples), with mainly $L p$ SGs 2 to 14 . According to time of sampling (first flow or after draining) and to the run (first or second run, two days after), Legionella counts range from $5.10^{3}$ to $2.10^{7}$ CFU.L $L^{-1}$ of water (for culture) and from $9.10^{3}$ to $15.10^{7}$ cells. $\mathrm{L}^{-1}$ of water (for the FISH method). For both detection methods, water Legionella concentrations are significantly greater in the first flow than after draining ( $p$ $=0.001$, paired test).

The association between PF incidence and shower water quality has been studied for different concentration thresholds, according to the analytical techniques that were used (two thresholds for the culture, and three for

Table 4: Distribution of antibody titers among cases and non cases of PF, and measure of association.

\begin{tabular}{llll}
\hline $\begin{array}{l}\text { Antibody } \\
\text { titers }\end{array}$ & $\begin{array}{l}\text { Number of subjects } \\
\text { with Pontiac fever }\end{array}$ & $\begin{array}{l}\text { Number of subjects } \\
\text { without Pontiac fever }\end{array}$ & RR (and $\left.p^{*}\right)$ \\
\hline $1 / 16$ & 5 & 94 & $1.39(0.34)$ \\
$1 / 32$ & 2 & 39 & $1.27(0.49)$ \\
$1 / 64$ & 3 & 77 & $0.94(0.61)$ \\
$1 / 128$ & 2 & 24 & $2.08(0.27)$ \\
$1 / 256$ & 2 & 14 & $3.45(0.12)$ \\
$1 / 512$ & 0 & 6 & $p=0.78$
\end{tabular}

\footnotetext{
* $\mathrm{p}$ value are from one-sided tests
}

the FISH technique). Results (table 5) suggest that a contamination level measured by the FISH technique exceeding $10^{4}$ Legionella. $\mathrm{L}^{-1}$ of water is associated with an increased risk of PF $(p=0.04)$. The rate of PF is also enhanced for greater contamination levels $(\mathrm{RR}=1.83$ [not significant $]$ and $2.12[\mathrm{p}=0.05]$, respectively for concentrations of $10^{5}$ and $10^{6}$ Legionella. $\mathrm{L}^{-1}$ detected by FISH). On the contrary, no statistically relevant association was observed between the levels of culturable Legionella and the PF incidence. This finding suggests a better sensitivity of the FISH technique to characterize exposure to infectious Legionella. When the two other definitions of a PF episode are accommodated, levels of $10^{4}$ Legionella. $\mathrm{L}^{-1}$ of water assayed by the the FISH method are also associated with an increased incidence, although more weakly, with $\mathrm{p}$ values of 0.06 (fever associated or not with another symptom) and 0.08 (fever and another symptom) respectively.

\section{Risk factors}

Age, gender or medical history were not associated with incidence of $\mathrm{PF}$, as defined in our study. The only factor that showed a statistically significant association with the "case" condition was immunosuppressive therapy ( $R R=$ $4.7, \mathrm{p}=0.02)$.

\section{Discussion}

This work proposes an operational definition of PF for surveillance and epidemiological investigation. The originality of this study is to lean not on an epidemic situation but on follow-up, during 4 months, of an elderly population residing in nursing homes. Taking a shower was the exposing activity. Legionella concentrations were measured both in hot-water and aerosols of showers, using culture and fluorescent in situ hybridisation (FISH) methods. The proposed definition of PF corresponds to the occurrence of at least one of the following "major" symptoms: headache, myalgia, fever or shivers, associated or not with other symptoms labelled as "minor". Such occurrence had to occur 24 to 48 hours after taking a shower contaminated with Legionella. The PF incidence is statistically increased when Legionella concentrations reach at least $10^{4}$ Legionella. $\mathrm{L}^{-1}$ in the shower water, using the FISH method, a level that seems to represent a threshold of risk. We are aware of no published epidemiological study on Legionnaires' disease that evaluated a minimal infective dose. However, a review of Legionnaire's episodes showed that whenever the probable source of contamination was found, water contained more than $10^{5} \mathrm{CFU} . \mathrm{L}^{-1}$ [2]. Two other definitions of a Pontiac episode were explored that focussed on fever, associated or not with other symptoms; this sensitivity analysis did not alter the results. 
Table 5: Cases distribution (and person-days at risk) for different levels of shower contaminations and associations' measure.

\begin{tabular}{|c|c|c|c|}
\hline Contamination threshold & Exposure categories & $\begin{array}{l}\text { Number of subjects with Pontiac } \\
\text { fever (person-days at risk) }\end{array}$ & $R R$ (and $p^{*}$ ) \\
\hline $\mathrm{CFU} \geq 10^{3} \mathrm{~L}^{-1}$ & $\begin{array}{l}\text { Exposed } \\
\text { Unexposed }\end{array}$ & $\begin{array}{l}10(24855) \\
13(42001)\end{array}$ & $1.30(0.33)$ \\
\hline $\mathrm{CFU} \geq 10^{4} \mathrm{~L}^{-1}$ & $\begin{array}{l}\text { Exposed } \\
\text { Unexposed }\end{array}$ & $\begin{array}{l}9(20928) \\
14(45928)\end{array}$ & I.4I (0.27) \\
\hline Cells-FISH $\geq 10^{4} \mathrm{~L}^{-1}$ & $\begin{array}{l}\text { Exposed } \\
\text { Unexposed }\end{array}$ & $\begin{array}{l}23(56245) \\
0(106 I I)\end{array}$ & UD** $(0.02)$ \\
\hline Cells-FISH $\geq 10^{5} \mathrm{~L}^{-1}$ & $\begin{array}{l}\text { Exposed } \\
\text { Unexposed }\end{array}$ & $\begin{array}{l}19(48265) \\
4(1859 I)\end{array}$ & $1.83(0.19)$ \\
\hline Cells-FISH $\geq 10^{6} \mathrm{~L}^{-1}$ & $\begin{array}{l}\text { Exposed } \\
\text { Unexposed }\end{array}$ & $\begin{array}{l}\text { II }(20185) \\
12(4667 I)\end{array}$ & $2.12(0.05)$ \\
\hline
\end{tabular}

*p value are from one-sided tests

**UD: undefined, because of 0 cases among unexposed

CFU: cells count by culture

Cells-FISH: cells count by FISH method

The description of PF in our study is unusual in several aspects: the study population and location, the source of the exposure and how it was ascertained.

\section{Study population and epidemiologic particularities of the results}

Our study describes for the first time, to our knowledge, the incidence of PF in a population of elderly people in nursing homes. Previous studies have described epidemic Pontiac episodes with spa (with jacuzzi), decorative fountains $[2,5,6,13,26-28]$, in relation with cooling towers [4], and also among workers involved in cleaning activities with high pressure water in confined spaces $[3,17,20,29]$. In most studies, subjects (usually young and not living continuously in the setting where exposure took place) were exposed during a short period (generally not exceeding ten days) to a common source, a situation that facilitates linkage between a cluster of symptoms among several individuals and a common source of exposure. On the contrary, our study describes symptoms of PF among subjects who may be exposed iteratively and individually. In this "endemic" context, however, cases appeared on a grouped mode since, besides 10 sporadic cases, all others among 23 who met the case definition occurred on a short period among subjects belonging to three nursing homes. In reference to epidemiologic data available in the literature, the incidence rate calculated in this study expresses this particular context. Indeed, previous papers have described very high attack rates of PF, about 70 to $90 \%$ [1] in an epidemic setting. On the contrary, when PF episodes occur in the community in a non epidemic setting, the mild severity of the symptoms can lead to underestimation of true incidence, these banal symptoms being easily overlooked [5]; hence, in a population follow-up setting like in our study, data collection might well miss some cases.
Sera titers of 1/256 appear here as being linked to cases of PF with a relative risk of $3.5(\mathrm{p}=0.12)$. Interestingly, this corresponds to the definition of the French National Institute of Health Surveillance (InVS) of a probable case of Legionnaires'disease [30]. Our results concerning the antigenuria ( 0 positive antigenuria for 23 subjects are similar to those described in some studies about legionellosis $[3,10,20]$. Six subjects who did not meet the proposed definition criteria of PF exhibited high titers of antibody $(>1 / 128)$, an intriguing observation. First, one should consider the small number of cases, allowing for sampling variability. This might also be explained by cross-reactions of antibodies detection in relation with the indirect immunofluorescence technique that is used. These crossreactions are many and were described for mycobacteries, leptospires, Chlamydia, Mycoplasma, Citrobacter, Campylobacter and Coxiella burnetii [31]. Moreover, Legionella encountered in human pathology generally belong to the pneumophila species. In our study, except Lp SG6, the other species observed among subjects with high levels of antibody who did not meet our definition of PF, belong to the non pneumophila species (anti-L. jordanis, anti-L. micdadei, anti-L. dumoffii and anti-L. Bozemanii). This also can be explained by the possibility of cross-reactions between different serogroups and different species of Legionella [32]. The most frequent symptoms that were exhibited by these subjects were cough (5/6), dyspnea (3/6), diarrhoea $(3 / 6)$ and headaches $(3 / 6)$. Although symptoms occurred in the three days following a shower, these subjects did not comply with our definition either because they only presented "minor symptoms", or because Legionella had not been detected in the showers they used.

In accord with other authors, age, gender and smoking habits are not found as risk factors for Pontiac fever $[10,11]$. This condition might even affect preferentially 
young subjects, with typical ages among cases in published epidemics ranging between 30 to 40 years $[3,4,10$ 13]. These figures are not comparable to ours since the average age of our elderly population among cases of PF was 82 years, similar to subjects who did not exhibit PF symptoms.

Among clinical risk factors that have been evaluated in the present study (a history of respiratory conditions, sicknesses impairing the immunity system such as diabetes, cancer, cardiovascular conditions and dementia such as Alzheimer's disease), only immunosuppressive therapy was associated with the incidence of PF $(p=0.02)$. This very risk factor had been also described in a study where prevalence of community respiratory conditions was compared between subjects residing in nursing homes and at home [33].

\section{Source and measure of exposure}

Aerosolised Legionella reached greater concentrations during the first minute, as previously described by several authors [34,35]. One limitation of this study resides in the semi-ecological character of exposure assessment. Indeed, exposure was not assessed at an individual level but by groups of subjects. All showers could not be systematically sampled and we assigned to a shower A (not sampled) the same quality as shower B (sampled) on criteria based on the existence of a common water column feeding the two showers. The resulting exposure misclassification is a Berkson type error $[36,37]$. It tends to lessen statistical power by increasing the variances estimates of the association; however it does not biase the point estimate, when the average group exposure is correctly represented by the measured concentrations.

Moreover, we have made the hypothesis that the hotwater Legionella contamination remained stable during the whole follow-up period. Now, only two measurements of water contamination were done at the end follow-up period in each nursing home to characterize exposure along the study. The validity of this assumption depends therefore on the time variability of the shower water contamination, whose avaluation is under way. It also depends upon other factors such that sensitivity and specificity of the sampling and analytical methods that were used $[8,25]$. Because the culture method has not the capacity to detect all viable bacteria that are sampled in the environment, due to their very diverse physiological states [38] and to environmental stress, conditions that led to the concept of "viable but not culturable bacteria" [39-41], there is some degree of underestimation of bacterial concentrations. Molecular approaches like the FISH technique might provide more representative concentration estimates, leading to improved exposure assessment to bacterial pathogens. Figures with the FISH method do not exist to date.

\section{Conclusion}

Our epidemiological findings back the operational definition of the PF that we propose. It needs to be confirmed by others studies. The investigation is still going on in order to include a thousand of volunteers, a number that should ensure a greater statistical power.

\section{Abbreviations}

PF : Pontiac fever

Lp: Legionella pneumophila

L. feeleii: Legionella feeleii

L. micdadei : micdadei

L. anisa: Legionella anisa

SG (s): serogroup (s)

anti-Lp: anti Legionella pneumophila

anti-L.: anti Legionella

AFNOR: Agence Française de Normalisation

FISH: Fluorescent In Situ Hybridisation

RR: Relative Risk

CDC: Center of Diseases Control

INVS: Institut National de Veille Sanitaire (National institute of Medical Surveillance)

MAS: Microbial Air Monitoring System

UFC: Colony-Forming Units

* Asterisked abbreviations are not defined in the body of the text

Financial and non-financial competing interests The author(s) declare that they have no competing interests.

\section{Authors' contributions}

TP was involved in the epidemiological survey. He performed data statistical analysis and wrote the manuscript. 
MAD carried out the environmental analyses (aerosols and water); she participated in its design and coordination and helped to draft the manuscript.

DZN and HP designed and carried out the survey studies, participated in the data analysis and helped for drafting the manuscript.

LM conceived the study, and participated in its design and coordination and helped to draft the manuscript and revising it critically.

\section{All authors read and approved the final manuscript.}

\section{Acknowledgements}

This study was funded by AFSSE (French Agency for Environemental Sanitary Security), the French ministry of Health and Véolia. M. Deloge-Abarkan was recipient of a doctoral scholarship from ADEME and EDF. The design of the aerosol exposure assessment was extensively discussed with Enric Robine, from CSTB, the French Building Research Center. The water system critical point analysis procedure was elaborated by Veolia Environnement. Nathalie Diguio, a Master student at Inserm, contributed to the study follow-up.

Participation to Lory MOUCHOT and Lahoucine BENAMGHAR to the statistical analysis is also acknowledged.

The authors are indebt towards the local medical authorities and the elderly persons who volunteered to participate to the study.

The staff of the nursing homes is also thanked; they cannot all be cited.

Brigitte Risse and Maryse Fiorani, from the Clinical Investigations Center of the Nancy University Hospital (coordinator: Anca Radauceanu) were responsible of the follow-up; their role was pivotal.

\section{References}

I. Pancer K, Stypulkowska-Misiurewicz H: Pontiac fever - non-pneumonic legionellosis. Przegl Epidemiol 2003, 57:607-12.

2. Fields BS, Haupt T, Davis JP, Arduino MJ, Miller HP, Butler JC: Pontiac fever due to Legionella micdadei from whirlpool Spa: possible role of bacterial endotoxin. J Infect Dis 200I, 184:I289-92.

3. Castor ML, Wagstrom EA, Danila RN, Smith KE, Naimi TS, Besser JM, Peacock KA, Juni BA, Hunt JM, Bartkus JM, Kirkhorn SR, Lynfield R: An outbreak of Pontiac fever with respiratory distress among workers performing high-pressure cleaning at a sugar-beet processing plant. J Infect Dis 2005, 191:1530-37.

4. Mori M, Hoshino K, Sonoda $H$, Yoshida $H$, Yabuuchi E, Yamashiro $Y$, Koide M, Saito A, Kishimoto T, Furuhata K: An outbreak of Pontiac fever due to Legionella pneumophila serogroup 7. I. clinical aspects. Kansenshogaku Zasshi 1995, 69:646-53.

5. Jones TF, Benson RF, Brown EW, Rowland JR, Crosier SC, Schaffner $\mathrm{W}$ : Epidemiologic investigation of a restaurant-associated outbreak of Pontiac fever. Clinical Infectious Diseases 2003, 37:1292-7

6. Benin AL, Benson RF, Arnold KE, Fiore AE, Cook PG, Williams LK, Fields B, Besser RE: An outbreak of travel-associated Legionnaires disease and Pontiac fever: the need for enhanced surveillance of travel-associated legionellosis in the United States. J Infect Dis 2002, 185:237-43.

7. Avril JL, Dabernat H, Denis F, Monteil H: Epidémiologie et pouvoir pathogène de Legionella. In Bactériologie Clinique Edited by: Ellipses. Paris; 1992:309-18.

8. Bornstein N, Fleurette J: Legionella. In Manuel de bactériologie clinique Edited by: Elsevier. Paris; 1994:106I-87.
9. Fraser DW, Deubner DC, Hill DL, Gilliam DK: Nonpneumonic, short-incubation-period Legionellosis (Pontiac fever) in men who cleaned a steam turbine condenser. Science 1979, 205:690-I.

10. Friedman S, Spitalny K, Barbaree J, Faur Y, Mckinney R: Pontiac fever outbreak associated with a cooling tower. Am J Public Health 1987, 77:568-72.

II. Goldberg DJ, Wrench JG, Collier PW, Emslie JA, Fallon RJ, Forbes GI, McKay TM, Macpherson AC, Markwick TA, Reid D: Lochgoilhead fever: outbreak of non-pneumonic legionellosis due to Legionella micdadei. Lancet 1989, 1:316-8.

12. Cordes LG, Fraser DW: Legionellosis: Legionnaires' disease; Pontiac fever. Med Clin North Am 1980, 64:395-4I6.

13. Fenstersheib MD, Miller M, Diggins C, Liska S, Detwiler L, Werner SB, Lindquist D, Thacker WL, Benson RF: Outbreak of Pontiac fever due to Legionella anisa. Lancet 1990, 336:35-7.

14. Kaufmann AF, Mcdade JE, Patton CM, Bennett JV, Skaliy P, Feeley JC, Anderson DC, Potter ME, Newhouse VF, Gregg MB, Brachman PS: Pontiac fever: isolation of the etiologic agent (Legionella pneumophila) and demonstration of its mode of transmission. Am J Epidemiol 198I, I I 4:337-47.

15. Luttichau HR, Vinther C, Uldum SA, Moller J, Faber M, Jensen JS: An outbreak of Pontiac fever among children following the use of a whirlpool. Clin Infect Dis 1998, 26:1374-8.

16. Miller LA, Beebe JL, Butler JC, Martin W, Benson R, Hoffman RE, Fields BS: Use of polymerase chain reaction in an epidemiologic investigation of Pontiac fever. J Infect Dis 1993, 168:769-72.

17. Herwaldt LA, Gorman GW, McGrath T, Toma S, Brake B, Hightower AW, Jones J, Reingold AL, Boxer PA, Tang PW: A new Legionella species, Legionella feeleii species nova, causes Pontiac fever in an automobile plant. Ann Intern Med 1984, 100:333-8.

18. Hunt DA, Cartwright KA, Smith MC, Middleton J, Bartlett CL, Lee JV, Dennis PJ, Harper D: An outbreak of Legionnaires' disease in Gloucester. Epidemiol Infect 1991, 107:|33-41.

19. Thacker SB, Bennett JV, Tsai TF, Fraser DW, Mcdade JE, Shepard CC, William KH Jr, Stuart WH, Dull HB, Eickhoff TC: An outbreak in 1965 of severe respiratory illness caused by the Legionnaires' disease bacterium. J Infect Dis 1978, I38:5 I2-9.

20. Gregersen P, Grunnet K, Uldum SA, Andersen BH, Madsen H: Pontiac fever at a sewage treatment plant in the food industry. Scand J Work Eviron Health 1999, 25:291-5.

21. U.S. EPA (United States Environnemental Protection Agency): Exposure Factors Handbook. [http://www.epa.gov/NCEA/pdfs/efh/ sect|5a.pdf].

22. Amann R, Ludwig W, Schleifer K-H: Philogenetic Identification and in situ detection of individual microbial cells without cultivation. Microbiological. Reviews 1995, 59:143-169.

23. Grimm D, Merkert H, Ludwig W, Schleifer K-H, Hacker J, Brand BC: Specific detection of Legionella pneumophila : construction of a new I6S rRNA-Targeted oligonucleotide probe. Applied and Environmental Microbiology 1998, 64:2686-90.

24. AFNOR (Association Française de Normalisation): Qualité des eaux. Recherche et dénombrement des Legionella spp et de Legionella pneumophila, méthode générale par ensemencement direct et après concentration par filtration sur membrane ou centrifugation. AFNOR Report no:T90-43I.

25. Buchbinder S, Trebesius K, Heesemann J: Evaluation of detection of Legionella spp. in water samples by fluorescence in situ hybridation, PCR amplification and bacterial culture. International Journal of Medical Microbiology 2002, 292:24I-5.

26. Mangione EJ, Remis RS, Tait KA, McGee HB, Gorman GW, Wentworth BB, Baron PA, Hightower AW, Barbaree JM, Broome CV: An outbreak of Pontiac fever related to whirlpool use, Michigan 1982. JAMA 1985, 253:535-9.

27. Gotz HM, Tegnell A, De Jong B, Broholm KA, Kuusi M, Kallings I, Ekdahl K: A whirlpool associated outbreak of Pontiac fever at a hotel in Northern Sweden. Epidemiol Infect 200I, 1 26:24I-7.

28. Spitalny KC, Vogt RL, Orciari LA, Witherell LE, Etkind P, Novick LF: Pontiac fever associated with a whirlpool spa. Am J Epidemiol 1984, 120:809-17.

29. Armstrong CW, Miller GB Jr: A 1949 outbreak of Pontiac feverlike illness in steam condenser cleaners. Arch Environ Health 1985, 40:26-9. 
30. Campese $C, C$ he $D$, Maine $C$, Jarraud S, Bitard D: Les légionelloses déclarées en France en 2004. Bulletin Epidémiologique Hebdomadaire (BEH) no.26/2005 .

31. Bornstein N, Fleurette J, Bosshard S, Bouvet C, Thouvenot D, Aymard M: Evaluation of the incidence of serological cross reactions between Legionella and Mycoplasma or Chlamydia. Pathol Biol 1984, 32:165-8.

32. Lo Presti F, Riffard S, Meugnier H, Reyrolle M, Lasne Y, Grimont PA, Grimont F, Vandenesch F, Etienne J, Fleurette J, Freney J: Legionella taurinensis sp. nov., a new species antigenically similar to Legionella spiritensis. Int J Syst Bacteriol 1999, 49:397-403.

33. Martinez-Moragon E, Garcia Ferrer L, Serra Sanchis B, Fernandez Fabrellas E, Gomez Belda A, Julve Pardo R: Community-acquired pneumonia among the elderly: differences between patients living at home and in nursing homes. Arch Bronconeumol 2004, 40:547-52.

34. Dennis PJ, Wright AE, Rutter DA, Death JE, Jones BP: Legionella pneumophila in aerosol from shower baths. J Hyg (Lond) 1984, 93:349-53

35. Breiman RF, Fields BS, Sanden GN, Volmer L, Meier A, Spika JS: Association of shower use with Legionnaires' disease. Possible role of amoebae. JAMA 1990, 263:2924-26.

36. Steeland K, Deddens JA: Design and analysis of studies in environmental epidemiology. In Topics in environmental epidemiology New York, Oxford: Oxford University Press; 1997:9-27.

37. Künzli N, Tager IB: The semi-individual study in air pollution epidemiology: a valid design as compared to ecologic studies. Envir Health Perspect 1997, 105: 1078-83.

38. Maul A, Vagost $D$, Block JC: Microbiologie des réseaux de distribution. In Stratégie d'échantillonnage pour analyse microbiologique sur réseaux de distribution Edited by: Lavoisier. Paris; I998: I-2I.

39. Federighi M: Les formes viables non cultivables des bactéries: point de vue et retour d'expérience d'un hygiéniste. Bulletin de la Société Française de Microbiologie 2004, 19:237-44.

40. Colwell RR, Grimes DJ: Nonculturable microorganisms in the environment Washington, DC: American Society for Microbiology; 2000.

41. Kell DB, Kaprelyants AS, Weichart DH, Harwood CR, Barer MR: Viability and activity in readily culturable bacteria: a review and discussion of the practical issues. Antonie van Leeuwenhoek 1998, 73:169-87.

42. Bonnard $R$ : Le risque biologique et la méthode d'évaluation du risque - Rapport final. Unité d'Evaluation des Risques Chroniques 2001 [http://www.sante.gouv.fr/htm/dossiers/etud impact/ risqbio ei72.pdf].

\section{Pre-publication history}

The pre-publication history for this paper can be accessed here:

http://www.biomedcentral.com/1471-2458/6/112/pre pub
Publish with Biomed Central and every scientist can read your work free of charge

"BioMed Central will be the most significant development for disseminating the results of biomedical research in our lifetime. "

Sir Paul Nurse, Cancer Research UK

Your research papers will be:

- available free of charge to the entire biomedical community

- peer reviewed and published immediately upon acceptance

- cited in PubMed and archived on PubMed Central

- yours - you keep the copyright

Submit your manuscript here:

http://www.biomedcentral.com/info/publishing_adv.asp
BioMedcentral 